\title{
DIVERSITY OF GROUND BEETLES (CARABIDAE) IN THE PLANTATIONS OF FAST GROWING TREES
}

\author{
P. Štastná
}

Received: June 6, 2012

\begin{abstract}
ŠŤASTNÁ, P.: Diversity of ground beetles (Carabidae) in the plantations of fast growing trees. Acta univ. agric. et silvic. Mendel. Brun., 2012, LX, No. 6, pp. 309-316

The species diversity of ground beetles (Carabidae) was monitored in the plantations of fast growing trees (poplars and willows) in the District of Žd'ár nad Sázavou, Czech Republic (faunistic square 6463). Relations between age and type of vegetation and biodiversity were observed. Samples were collected from pitfall traps at monthly intervals from May to October in 2008. In total, 36 species of Carabidae represented by 912 specimens were entrapped in the 4 monitored plots. Basic synecologic characteristics (dominance, species diversity, evenness and Jaccard similarity index) were evaluated. The most numerous species in the plot No. 1 was Abax parallelepipedus (99 specimens), in the plot No. 2 Limodromus assimilis (112 specimens), in the plot No. 3 Amara montivaga (32 specimens) and in the plot No. 4 Poecilus cupreus (52 specimens). The majority of adaptable species was recorded in the plot No. 1, which signifies a well-regenerated secondary biotope. Shannon's diversity index (2.78) were the highest in the plot No. 3, and the highest evenness was also in the plot No. 3 (0.84). The highest similarity expressed by the Jaccard similarity index was observed between the plots No. 2 and 4, the lowest between the plots No. 1 and 3. Fast growing trees plantations host similar fauna of ground beetles as the surrounding agroecosystems with eurytopic species dominating. Specific species of cultivated trees do not probably significantly affect the species composition of ground beetles, but the density of vegetation can affect the abundance of species present. Two threatened species of (Brachinus explodens and Cicindela campestris) according to Decree No. 395/1992 Coll. were identified in the monitored plots.
\end{abstract}

Carabidae, fast growing trees, synecologic characteristics

Limited reserves of fossil fuels lead to exploatation of other sources of energy among which the most significant is the use of biomass (Noskievič et al., 1996). Its utilization is studied by phytoenergetics (Zimolka, 2004). Fast growing trees are perceived as a very suitable energy source (Celjak \& Boháč, 2008; Celjak, 2010).

The most common range of species are genera Populus and Salix. The aim of plantation cultivation is to exhaust the maximum production of biomass from the smallest area possible. Therefore trees are planted in straight rows at regular distances, to facilitate subsequent care and harvesting. In case these crops will be widely planted in the future, it is necessary to evaluate their impact on the habitat itself and its surroundings in detail, especially with regard to the level of biodiversity. According to
Boháč (2008), biodiversity in energy crop plantations may be affected both positively and negatively. Plantations may increase the overall biodiversity in agricultural landscapes, if they provide refuge to some mammals and birds, predatory and parasitic species of invertebrates, especially insects attacking crop pests. On the other hand, these plantations can host some invasive species or pests.

The biodiversity in plantations of fast growing trees has been studied by many authors, e. g. Liesebach \& Mecke (2003), Ulrich et al. (2004), Semere \& Slater (2007a, 2007b), Boháč et al. (2007), Jahnová (2009), and Havlíčková \& Kašparová (2010).

Differences in gross indicators of vegetation biodiversity from forest or agricultural ecosystems should establish the suitability of planting fastgrowing trees in the vicinity of near-natural habitats. 
The total area of willow plantations in Europe is about 20000 ha. In Central and Southern Europe, poplar short rotation coppice are grown in about 10000 ha (Weger, 2009).

The objective of this research was to determine whether fast growing species are more colonized by eurytopic species, or whether they can be settled by relict species more often than agrocenoses. Ground beetles (Carabidae) were used as a model for the assessment.

\section{MATERIAL AND METHODS}

The research site is located in the BohemianMoravian Highlands, the region of Žd'árské vrchy, about half a mile west of the Bystřice nad Pernštejnem, in the area called Domanínek (49 $32^{\prime}$ $\left.\mathrm{N}, 16^{\circ} 15^{\prime} \mathrm{E}\right)$. The altitude is $560 \mathrm{~m}$, mean annual temperature is $6.4^{\circ} \mathrm{C}$ and average precipitations reach $651 \mathrm{~mm}$. Used meteorological data were obtained from the meteorological station ČHMÚ Bystřice nad Pernštejnem.

Sampling was carried out at 4 selected plots. At each plot a row of five traps was installed. The traps were placed in $5 \mathrm{~m}$ distance and covered by a top of acrylic glass. Monitoring was conducted from May to the end of October in 2008. The material was collected from the traps at monthly intervals (on dd.mm.yyy, 25. 5. 2008, 29. 6. 2008, 2. 8. 2008, 7. 9. 2008 and 4. 10. 2008). A 4\% formaldehyde with a detergent addition as a wetting agent was used as fixative solution. After collection, the material was converted into a permanent fixation in $70 \%$ alcohol. Determination of species of the Carabidae was performed using Hưrka's monograph (1996). The nomenclature is according to Audisio \& Taglianti (2011).

Species dominance, Shannon's diversity index, evenness, and Jaccard similarity index were evaluated for each monitored plot. Classification according to Tischler (1965) was used to evaluate the count of dominance, i.e. species eudominant above $10 \%$, dominant 5 to $10 \%$, subdominant 2 to $5 \%$, recedent 1 to $2 \%$, and subrecedent below $1 \%$.

Species were classified according Hůrka et al. (1996) into groups (R, A and E) according to the extension of ecological valence of taxons and their relation to habitat. Species of Group E are eurytopic species without special demands on the habitat type and quality. We classify here species from varying of habitats, species inhabiting strongly anthropogenically influenced landscape and expansive species. Types of Group A are more adaptable species, found in more or less natural habitats. This group consists mainly of species typical for forests, meadows, pastures and coastal species of standing and flowing water. The R group comprises taxa with the narrowest ecological potence, rare or endangered species accompanying natural, little influenced habitats.

\section{Characteristics of the studied plots}

Plot No. 1

The plot was located in the ecosystem of fast growing trees in a poplar plantation. It was a clone of J-105 (Populus nigra x P. maximowiczii), the plot was without understory. The trees were planted $70 \mathrm{~cm}$ from each other with $70 \mathrm{~cm}$ in between rows and with a gap of about $260 \mathrm{~cm}$. The vegetation was established in 2002.

\section{Plot No. 2}

The second plot is located approximately $100 \mathrm{~m}$ from the first one and represented willow, clone S-310 (Salix viminalis) monoculture. The trees were planted $70 \mathrm{~cm}$ from each other with $70 \mathrm{~cm}$ in between rows and with a gap of about $260 \mathrm{~cm}$. The vegetation was established in April 2001, the first harvest took place in autumn 2008, after collecting. Relatively tall grass and other plants, such as Taraxacum officinale, Rumex acetosa, Plantago lanceolata, and Leucanthemum vulgare, were growing here.

\section{Plot No. 3}

The control plot was located in an adjacent meadow, where no agricultural machinery was used. The vegetation cover was dominated by Taraxacum officinale, Achillea millefolium, Anthriscus sylvestris, Rumex acetosa, Plantago lanceolata, Convolvulus arvensis, Elytrigia repens, Poa pratensis, and Phleum pratense.

\section{Plot No. 4}

Similary to the first plot, the fourth one was a poplar plantation, clone J-104 (Populus nigra $\mathrm{x}$ P. maximowiczii). The trees were planted $70 \mathrm{~cm}$ from each other with $70 \mathrm{~cm}$ in between rows and with a gap of about $260 \mathrm{~cm}$. The vegetation was established in April 2001, the first harvest took place in autumn 2008 after collecting. The stinging Urtica dioica grew here almost exclusively. The downy burdock (Arctium tomentosum) occurred in the vicinity of the plantation.

\section{RESULTS AND DISCUSSION}

In total, 36 species of Carabidae represented by 912 specimens were collected in the monitored locations. The most numerous species in the plot No. 1 was Abax parallelepipedus (99 specimens), in the plot No. 2 Limodromus assimilis (112 specimens), in the plot No. 3 Amara montivaga (32 specimens) and in the plot No. 4 Poecilus cupreus (52 specimens). Shannon's diversity index was the highest in the plot No. 3 (2.78), followed by No. 4 (2.41), No. 2 (1.73), and No. 1 (1.57). Similarly, the evenness value was the highest in the plot No. 3 (0.84), followed by No. 4 (0.77), No. 2 (0.6), and No. 1 (0.55). Species dominance in the individual plots is given in Tab. I.-IV.

The greatest similarity (Jaccard similarity index) was observed between the plots No. 2 and 4, the lowest one was between the plots No. 1 and 3 (Tab. V). 
I: Plot 1 -species representation of Carabidae and ecological indices ( $N$ - number of specimens, $D-$ dominance)

\begin{tabular}{|c|c|c|}
\hline Species & $\mathbf{N}$ & D (\%) \\
\hline Abax parallelepipedus (Piller \& Mitterpacher, 1783) & 99 & 40.91 \\
\hline Abax parallelus (Duftschmid, 1812) & 3 & 1.24 \\
\hline Amara curta Dejean, 1828 & 1 & 0.41 \\
\hline Amara montivaga Sturm, 1825 & 2 & 0.83 \\
\hline Brachinus explodens Duftschmid, 1812 & 1 & 0.41 \\
\hline Calathus fuscipes (Goeze, 1777) & 1 & 0.41 \\
\hline Carabus hortensis Linnaeus, 1758 & 1 & 0.41 \\
\hline Carabus violaceus Linnaeus, 1758 & 2 & 0.83 \\
\hline Nebria brevicollis (Fabricius, 1792) & 1 & 0.41 \\
\hline Poecilus cupreus (Linnaeus, 1758) & 2 & 0.83 \\
\hline Pseudoophonus griseus (Panzer, 1797) & 10 & 4.13 \\
\hline Pterostichus melanarius (Illiger, 1798) & 1 & 0.41 \\
\hline Pterostichus strenuus (Panzer, 1797) & 1 & 0.41 \\
\hline number of specimens & 242 & \\
\hline number of species & 17 & \\
\hline Shannon diversity index & 1.57 & \\
\hline
\end{tabular}

II: Plot 2 - species representation of Carabidae and ecological indices ( $N$ - number of specimens, $D$-dominance)

\begin{tabular}{|c|c|c|}
\hline Species & $\mathbf{N}$ & $\mathbf{D}(\%)$ \\
\hline Abax parallelepipedus (Piller \& Mitterpacher, 1783) & 8 & 4.04 \\
\hline Amara aenea (De Geer, 1774) & 4 & 2.02 \\
\hline Amara curta Dejean, 1828 & 8 & 4.04 \\
\hline Amara equestris (Duftschmid, 1812) & 1 & 0.51 \\
\hline Amara montivaga Sturm, 1825 & 11 & 5.56 \\
\hline Amara plebeja (Gyllenhal, 1810) & 1 & 0.51 \\
\hline Anchomenus dorsalis (Pontoppidan, 1763) & 3 & 1.52 \\
\hline Badister lacertosus Sturm, 1815 & 1 & 0.51 \\
\hline Brachinus explodens Duftschmid, 1812 & 3 & 1.52 \\
\hline Calathus fuscipes (Goeze, 1777) & 2 & 1.01 \\
\hline Calathus melanocephalus (Linnaeus, 1758) & 5 & 2.53 \\
\hline Harpalus affinis (Schrank, 1781) & 1 & 0.51 \\
\hline Harpalus rubripes (Duftschmid, 1812) & 1 & 0.51 \\
\hline Limodromus assimilis (Paykull, 1790) & 112 & 56.57 \\
\hline Poecilus cupreus (Linnaeus, 1758) & 14 & 7.07 \\
\hline Pseudoophonus griseus (Panzer, 1797) & 17 & 8.59 \\
\hline Pterostichus melanarius (Illiger, 1798) & 1 & 0.51 \\
\hline Pterostichus strenuus (Panzer, 1797) & 5 & 2.53 \\
\hline number of specimens & 198 & \\
\hline number of species & 18 & \\
\hline Shannon diversity index & 1.73 & \\
\hline evenness & 0.6 & \\
\hline
\end{tabular}


III: Plot 3 - species representation of Carabidae and ecological indices ( $N$ - number of specimens, $D$ - dominance)

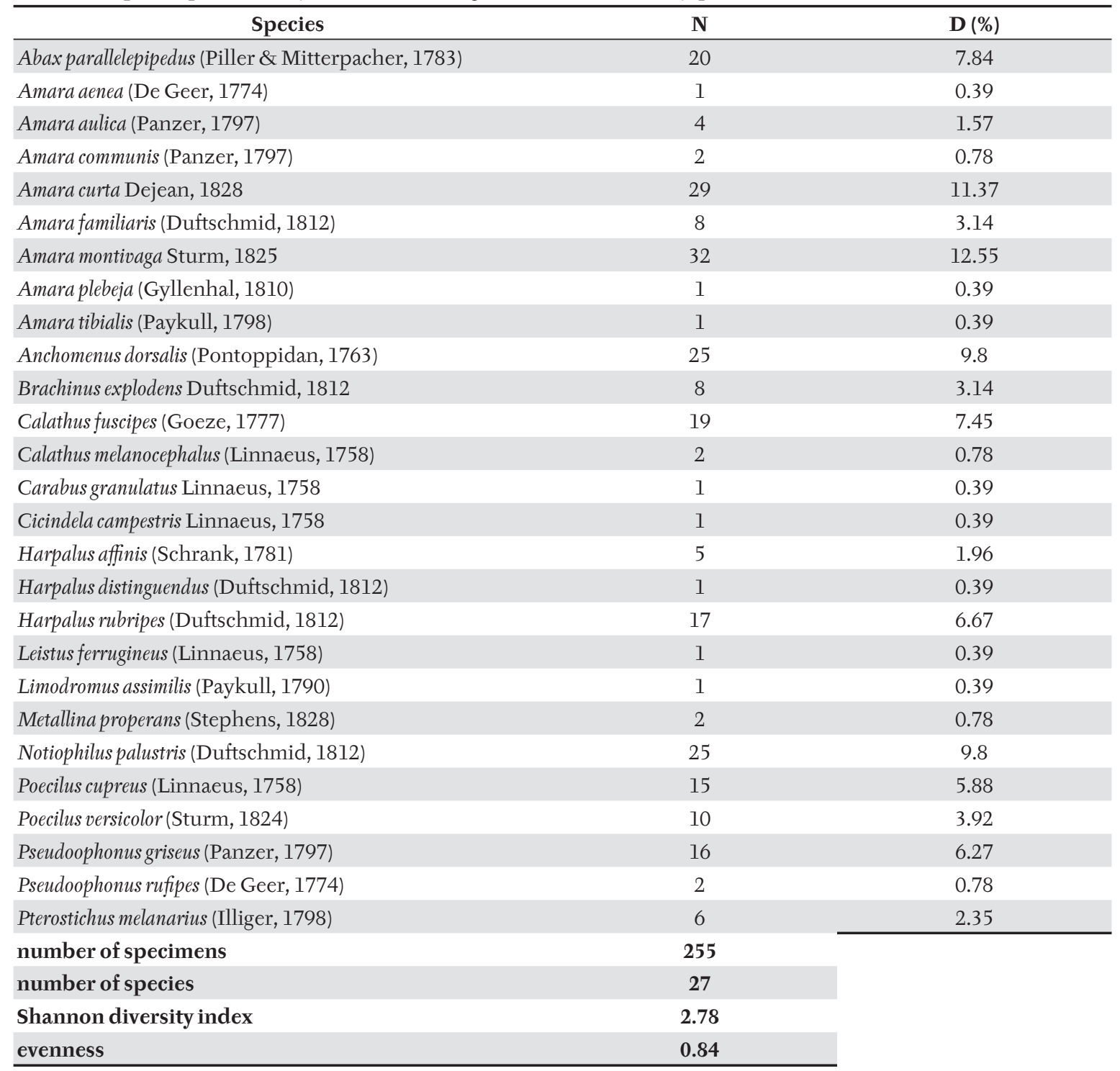

The plot No. 1 was dominated by eurytopic species (53\%), adaptable species were represented by $47 \%$ and relict species were not found at all. In the plot No. 2, eurytopic species strongly predominated (72\%) over the adaptable species (28\%), relict species were found at all. In the plot No. 3, eurytopic species predominated $(78 \%)$ over the adaptable species (22\%), too, and this was also the case in the plot No. 4, where eurytopic species accounted for $65 \%$ and adaptable species for 35\%. Relict species were not recorded in experiment (Fig. 1-4). The results indicate that fast growing tree plantations probably do not have any impact on the species composition of ground beetles. While trees are growing, shade humidity in the understory are increasing and thus species preferring shady habitats can become more abundant. This fact could be the cause of differences in the dominance of certain species in individual plots.
Occurrence of 2 threatened species of (Brachinus explodens and Cicindela campestris) according to Decree No. 395/1992 Coll. was recorded in the monitored plots. No species from the Red List of Threatened Species in the Czech Republic (Veselý et al., 2005) occurred.

Other authors researching biodiversity of epigeic beetles in fast growing trees plantations obtained very similar results. Jahnová (2009) conducted a research of epigeic beetles (Carabidae, Staphylinidae) in plantations of fast-growing plants (Dactylis glomerata, Arrhenatherum elatius, Phalaris arundinacea, and Helianthus tuberosus). In the selected sites she collected 594 specimens belonging to 25 species of ground beetles. The dominant species in communities were Poecilus cupreus, Pseudophonus rufipes, Calathus fuscipes, Harpalus aeneus, and Nebria brevicollis. All sites were dominated by eurytopic species over the adaptable ones. These outcomes are also confirmed by our results, when all plots 
IV: Plot 4-species representation of Carabidae and ecological indices ( $N$ - number of specimens, $D$-dominance)

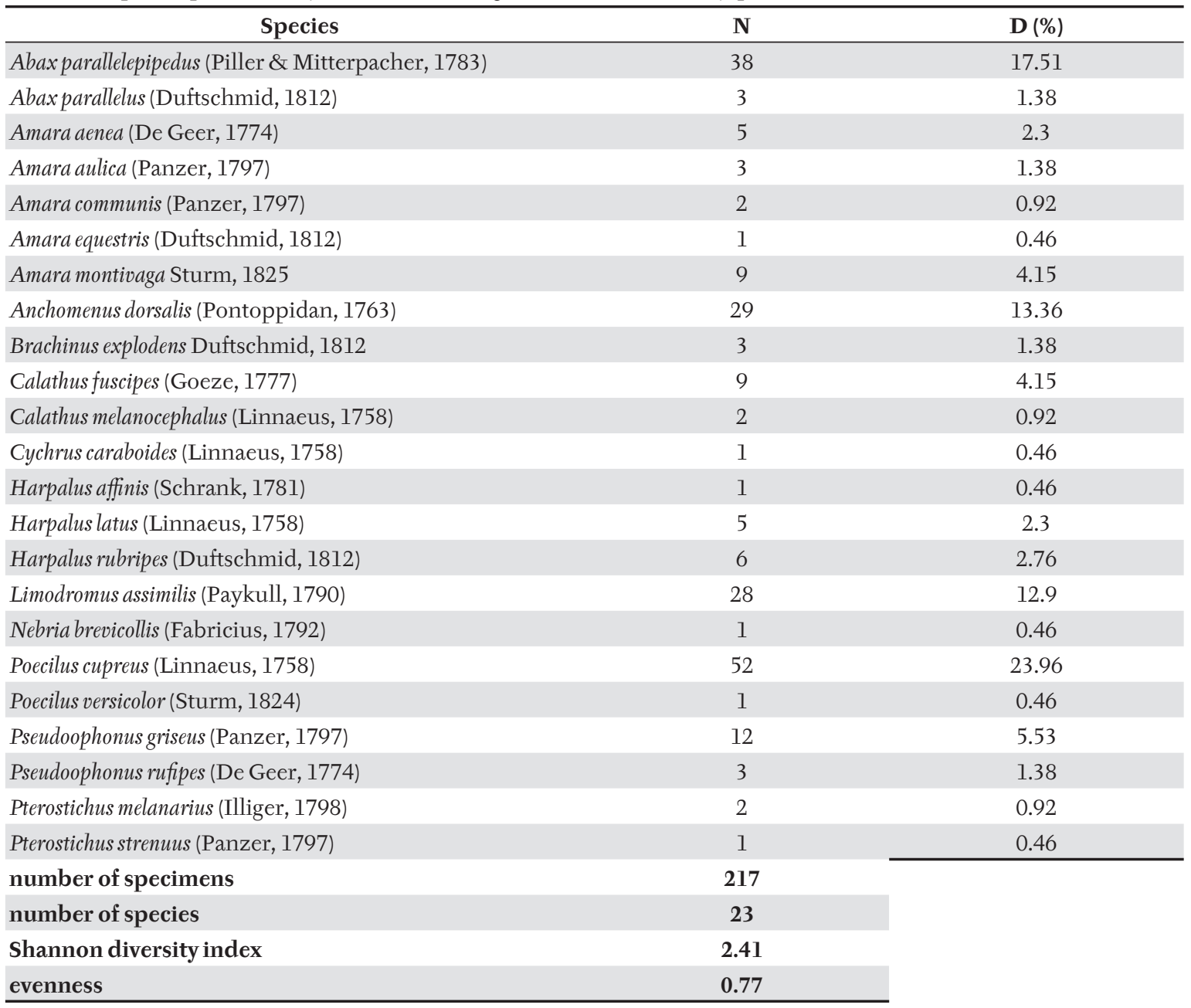

V: Jaccard similarity index (\%)

\begin{tabular}{lccc}
\hline & plot 4 & plot 3 & plot 2 \\
\hline plot 1 & 42.9 & 37.5 & 45.8 \\
plot 2 & 57.7 & 54.8 & \\
plot 3 & 51.5 & & \\
\hline
\end{tabular}

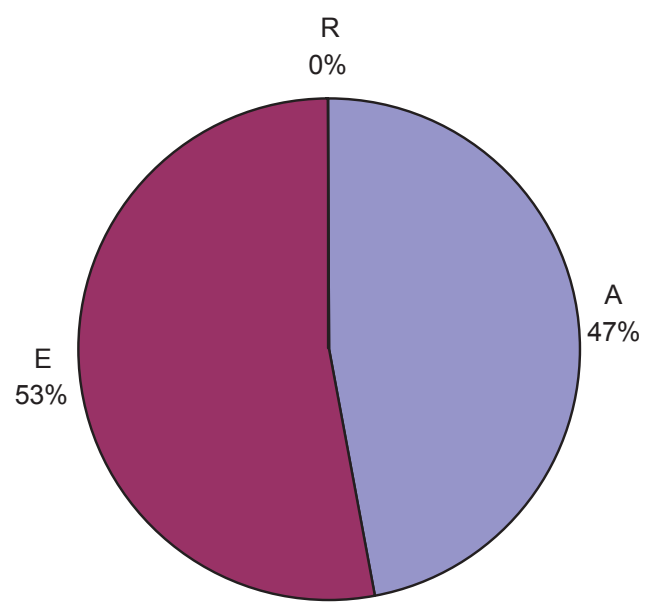

1: Categorization of carabid taxocoenosis by relictum on plot 1 are dominated by eurytopic species. Havlíčková \& Kašparová (2010) report 797 Carabidae specimens belonging to 32 species from the fast-growing tree plantations in 2010. The ratio between eurytopic and adaptable specimens was $59.35 \%$ to $40.65 \%$. They also did not record any relict species in

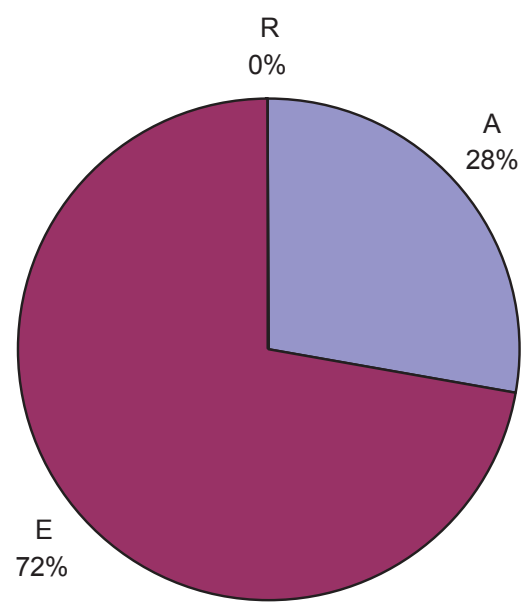

2: Categorization of carabid taxocoenosis by relictum on plot 2 


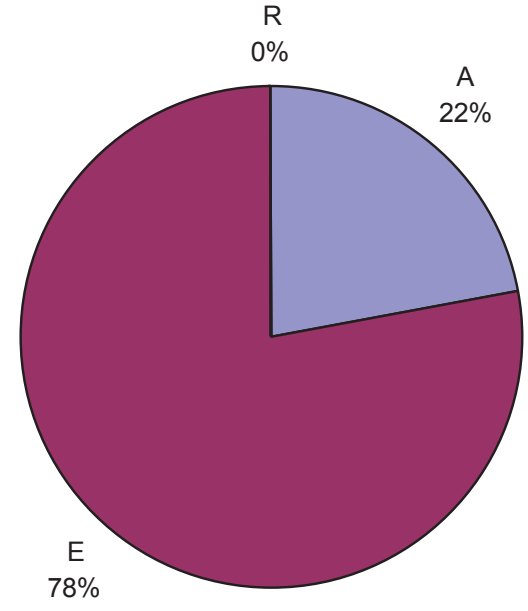

3: Categorization of carabid taxocoenosis by relictum on plot 3

the plantations. Boháč et al. (2007) investigated biodiversity in fast growing trees plantations at 6 sites, in particular poplar, alder and willow. They confirmed that the greatest impact on the invertebrate communities is exerted by surrounding agricultural landscape. They found that the numbers of species in individual surveyed plots are not much different. Relict species of ground beetles were neither found.

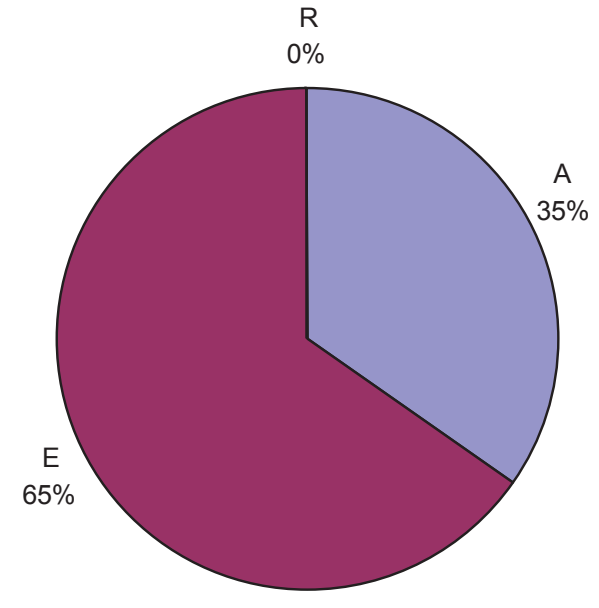

4: Categorization of carabid taxocoenosis by relictum on plot 4

Boháč (2008) further states that the energy crop plantations host a similar invertebrate fauna as the surrounding agroecosystems, which means that species with broad ecological valence are dominant. This is confirmed by our results, too. Communities of invertebrates in plantations are strongly influenced by the structure of surrounding countryside, particularly surrounding semi-natural habitats from where the species often penetrate to the plantations.

\section{SUMMARY}

The ground beetles were captured in pitfall traps in the vegetation of fast growing trees (poplars and willow) in the district of Ždár nad Sázavou. Sampling was carried out using pitfall traps at 4 selected plots. In each plot a line of five traps was installed. Traps were placed in $5 \mathrm{~m}$ distances. Samples were collected at monthly intervals from May to October in 2008. The main objective was to determine the biodiversity of the Carabidae in the fast growing trees plantations and to assess how these biotopes affect the surrounding habitat. Next, the research aimed to determine whether these plantations are colonized by eurytopic and adaptable species, or even relict species penetrate here. In total, 36 species of Carabidae with a total number of 912 specimens were entrapped in the 4 monitored locations. Basic synecologic characteristics (dominance, species diversity, evenness, and Jaccard similarity index) were evaluated. The most abundant species in the plot No. 1 was Abax parallelepipedus (99 specimens), in the plot No. 2 Limodromus assimilis (112 specimens), in the plot No. 3 Amara montivaga (32 specimens) and in the plot No. 4 Poecilus cupreus (52 specimens). Species diversity index was the highest in the plot No. 3 (2.78) and the highest evenness value was reached also in the plot No. 3 (0.84). From the perspective of relictness, all the plots were predominated by species of the E group, the species of R group were not represented at any location. The obtained results indicate that plantations of fast growing trees are inhabited by eurytopic species and the presence of individual species of Carabidae depends on the spectrum of species colonising plantations from the surrounding agroecosystems. The highest similarity Jaccard similarity index was observed between the plots No. 2 and 4, the lowest one was between the plots No. 1 and 3. 2 threatened species of (Brachinus explodens and Cicindela campestris) according to Decree No. 395/1992 Coll. were identified in the monitored plots. It can be concluded that the fast growing trees plantations host a fauna similar to that of surrounding agroecosystems.

\section{Acknowledgment}

This study was supported by the Research plan No. MSM6215648905 and IGA MENDELU TP4/2012. The author thanks to Zdeněk Laštůvka for his notes to the manuscript and Luboš Purchart for his help with determination. Eventually, my thanks belong to the following colleagues for their help with both outdoor and laboratory tasks: Lenka Pivodová, Hana Šefrová, Jaroslav Šafár̆, Vladimír Hula and Jan Bezděk. 


\section{REFERENCES}

AUDISIO, P., TAGLIANTI, A. V. (eds.), 2011: Fauna Europaea - Carabidae. Available online at: http:// www.faunaeur.org (cited 12.3.2012).

BOHÁČ, J., 2008: Biodiverzita na plantážích rychle rostoucích rostlin pro energetické účely. In Havlíčková, K.: Rostlinná biomasa jako zdroj energie. Výzkumný ústav Silva Taroucy pro krajinu a okrasné zahradnictví s Novou tiskárnou Pelhřimov, $83 \mathrm{~s}$.

BOHÁČ, J., CELJAK, I., WOTAVOVÁ, K., 2007: Communitites of Carabid beetles in plantations of fast growing plant species for energetic purposes. In: PENEV, L., ERWIN, T., ASSMANN, T. (eds.): Back to the Roots and Back to the Future: a synthesis between taxonomic, ecological and biogeographical approaches in Carabidology. XIII European Carabidologists Meeting, Blagoevgrad, August 20-24, 2007, 509 pp.

CELJAK, I., 2010: Pěstování topolů pro energetické účely - 1. Available online at: http://biom.cz/ (cited 13. 12. 2011).

CELJAK, I., BOHÁČ, J., 2008: Využití biomasy rychle rostoucích dřevin $\mathrm{v}$ energetice sídel. Available online at: http://biom.cz/cz/odborneclanky/ (cited 14. 12. 2011).

HAVLÍČKOVÁ, K., KAŠPAROVÁ, L., 2010: Sledování změn diverzity čeledi Carabidae ve výmladkové plantáži rychle rostoucích dřevin na lokalitě Peklov. Acta Pruhoniciana, 96: 47-52.

HŮRKA, K., 1996: Carabidae of the Czech and Slovak Republics. Kabourek, Zlín, 565 pp.

HU゚RKA, K., VESELÝ, P., FARKAČ, J., 1996: Využití střevlíkovitých (Coleoptera: Carabidae) k indikaci kvality prostředí. Klapalekiana, 32: 15-26.

JAHNOVÁ, Z., 2009: Společenstva epigeických brouků plantáží rychle rostoucích bylin. Thesis, University of South Bohemia in České Budějovice, $53 \mathrm{~s}$.
LIESEBACH, M., MECKE, R., 2003: The carabid fauna of short-rotation coppice plantation in comparison with that of a neighbouring barley field and a Norway spruce stand. Holzzucht, 54: 11-15.

NOSKIEVIČ, P., JUCHELKOVÁ, D., ČECH, B., 1996: Biomasa a její energetické využití. Frýdek Místek: VŠB-Technical University of Ostrava, $68 \mathrm{~s}$.

SEMERE, T., SLATER, F. M., 2007a: Ground flora, small mammal and bird species diversity in miscanthus (Miscanthus $\mathrm{x}$ giganteus) and reed canary-grass (Phalaris arundinacea) fields. Biomass \& Bioenergy, 31: 20-29.

SEMERE, T., SLATER, F. M., 2007b: Invertebrate populations in miscanthus (Miscanthus $\mathrm{X}$ giganteus) and reed canary-grass (Phalaris arundinacea) fields. Biomass \& Bioenergy, 31: 3039.

TISCHLER, W., 1965: Agrarökologie. Jena: VEB Gustav Fischer. 499 S.

VESELÝ, P., MORAVEC, P., STANOVSKÝ, J., 2005: Carabidae (střevlíkovití), s. 406-411. In: FARKAČ, J., KRÁL, D., ŠKORPÍK, M. (eds.), Red list of threatened species in the Czech Republic. Nature Conservation Agency of the Czech Republic, Prague, 760 pp.

ULRICH, W., BUSZKO, J., CZARNECKI, A., 2004: The contribution of poplar plantations to regional diversity of ground beetles (Coleoptera: Carabidae) in agricultural landscapes. Annales Zoologici Fennici, 41: 501-512.

WEGER,J., 2009:Hodnocenívlivu délkysklizňového cyklu výmladkové plantáže na produkční a růstové charakteristiky topolového klonu Max-4 (Populus nigra L. x P. maximowiczii Henry). Acta Pruhoniciana, 92: 5-11.

ZIMOLKA, J., 2004: Využití biomasy k energetickým účelům. In: Šnobl, J.: Rostlinná výroba IV. Prague, Czech University of Life Sciences Prague Prague, 119 pp.

Address

Dr. Ing. Pavla Štastná, Ústav zoologie, rybářství, hydrobiologie a včelařství, Mendelova univerzita v Brně, Zemědělská 1, 61300 Brno, Česká republika, e-mail: pavla.stastna@mendelu.cz 
